\title{
The Impact of Edutainment in Improving Learner Performance in Thermal Physics
}

\author{
Samuel Chingaipe Mbewe ${ }^{1}$, Adrian Habanyama ${ }^{2}$ \\ ${ }^{1}$ C/O School of graduate studies, The Copperbelt University, Kitwe, Zambia \\ ${ }^{2}$ Department of Physics, School of Mathematics and Natural sciences, The Copperbelt University, Kitwe, Zambia \\ *Corresponding author: chingaipesamuel@gmail.com \\ DOI: $10.29322 / I J S R P .10 .05 .2020 . p 10142$ \\ http://dx.doi.org/10.29322/IJSRP.10.05.2020.p10142
}

\begin{abstract}
The major research purpose of this study is to present the relevance of using edutainment approaches such as Computer Simulation and Poetry (CSP) to teach thermal physics to the learners. The use of edutainment as the teaching approach attract learner's attention more and increases learner's excitement and enthusiasm. The study was conducted in Chipangali District, Eastern Province of Zambia. The research study employed two instruments to collect data. The instruments used were an achievement test and a questionnaire. Data collected was proceeded by a pilot study mainly to determine the validity and reliability of the instruments. A quasi-experimental design was used in this study. The learners in the experimental group were instructed using edutainment approach that is poetry and computer simulation. The learners in control group were instructed using cooperative learning. A pre-test was administered to both before instruction in order to determine the learner's prior knowledge on the topic. A post-test was administered to both groups after the instruction to determine the learners' understanding of the topic. The Statistical Package for Social Sciences (SPSS) version 20 was used to obtain appropriate descriptive and inferential statistics. The results reviewed that edutainment approaches such as poetry and computer simulation had a positive impact on learners' academic performance in thermal physics. Therefore, the use of computer simulation and poetry should be encouraged in the teaching and learning process in order to enhance learners understanding of complex concepts in physics hence improving their performance.
\end{abstract}

Keywords: Edutainment, computer simulation, poetry, performance, thermal physics

\section{INTRODUCTION}

Physics is one of the subjects taught at Senior Secondary Schools in Zambian. It covers a variety of topics that require students to reason, think critically, and solve problems using laws, principles, and mathematical equations (Michael \& Josefa, 2017). The physics teachers are very much aware of the unpopularity and the poor performance of the learners in physics. Thus, the search for the method that can be used to capture the learner's attention and make them ready for a lesson.

Education currently has to be more interactive, engaging, experiential and meaningful rather than boring and unpleasant learning process. The education system should not only make learning enjoyable and active but also improving the learner's academic performance. Edutainment gives a new opportunity to every learner in class regardless of his/her abilities to acquire at the same level the knowledge in an interesting and joyous way.

The topic of thermal physics in the grade eleven (11) Zambian syllabus appears to be boring because it is normally taught in abstract and most of the learners do not perform well during examination. Most of the scientific concepts and principles in the topic thermal physics, they do not arouse learners' feelings and interest, and this causes the lesson to be boring to them. Therefore, poetry and computer simulation can be used to replace such boring lessons. These methods will motivate the learners into the mood of learning because amusement and joy are the main motives for learners to enjoy the learning activities. 
Physics plays a major role in enhancing the country's technology, industrial and scientific development. Therefore, physics is necessary for the economy of the country. It also plays an important role in driving innovations and development of the new technologies in the country. A country that is performing well scientifically, technologically and industrially has a sound economy. In order to have good economy, the quality of teaching and learning in physics has to improve. The materials used by the teacher in the teaching and learning of any physics topic determines the learner's performance. Our education system still consists of few interactive lessons that can stimulate the pupils learning, and make them to become creative thinkers and good innovators. Therefore, edutainment is a teaching and learning tool that can be used in order to motivate learners and to promote creative thinking skills. Good teaching material used by the teacher increases learner's attention and creativity. The importance of edutainment is to attract learner's attention and to make them focus during the learning process (Okan, 2003).

In order for learners to understand scientific concepts and principles easily, edutainment methods such as CSP are needed because they represent real life situation. Edutainment is a word derived from two terms education and entertainment. Meaning, edutainment is the form of entertainment that enables the learners to educated. This method of edutainment facilitates teaching and learning through visualization. Edutainment also helps to give chance to learners to understand scientific concepts and principles with less difficulties. Visual representations have been found to help explain scientific concepts and principles that are used to clarify natural phenomena (Gilbert \& Priest, 1997). Edutainment brings emotional motivational conditions such that the learning process is transformed into an active participation for the learners.

This study investigated the impact of edutainment in improving grade 11 learner's performance in thermal physics. The edutainment methods used in the study were computer simulation and poetry.

\section{RESEARCH ELABORATIONS}

\subsection{Statement of the Problem}

Studies have revealed that topics such as mechanics, optics, electromagnetism, and thermodynamics are difficult to understand. These topics were especially difficult for students who have not learned how to apply knowledge in novel and real-life situations (Michael \& Josefa, 2017). Many physics concepts taught at secondary school are very abstract and teachers do not normally present them to the learners in a concrete way. The evidence based on experimental studies suggests that we can improve learning by integrating computer simulations on topics that students find conceptually difficult (Candida, et al, 2014). Thermal physics is one of the difficult topics in the physics syllabus of Zambian which is taught in abstract because learners cannot visualise some of the concepts and principles thereby causing a poor performance. Thermal physics is the combined study of thermodynamics, statistics mechanics, and kinetic theory. The method a teacher uses should cultivate interest in learners and not learners to develop interest on their own. A teacher should be like a magnet and learners like magnetic materials. The teaching and learning process can be made more easily by capturing the mind of a learner and making the subject and material to be taught enjoyable (Nalan, 2015). Therefore, use of edutainment may lead to an easier understanding of these abstract concepts and principles.

The learner's performance in physics during the final examination at the national is very low as tested by Examination Council of Zambia (ECZ). Majority of the candidates who pass in physics examinations normally get satisfactory and credits, and fewer in merits and distinction. The tables 1 and 2 show a summary report by the Chief Examiner for learners' performance in physics 5054 for 2014 and 2017 School Certificate (SC) in Zambia. 
Table 1: 2014 SC Summary of Performance in Physics (5054) by Paper.

\begin{tabular}{|l|l|l|l|l|l|l|}
\hline \multirow{2}{*}{ Physics (5054) } & \multicolumn{2}{l}{ Candidature } & \multicolumn{2}{l|}{ Mean Score (\%) } & \multicolumn{2}{l|}{ Zero (\%) } \\
\cline { 2 - 7 } & 2013 & 2014 & 2013 & 2014 & 2013 & 2014 \\
\hline Paper 1 (Theory) & 4,434 & 4,450 & 61.75 & 57.25 & 0 & 0 \\
\hline Paper 2 (Theory) & 4,430 & 4,455 & 45.58 & 45.37 & 1 & 18 \\
\hline Paper 3 (Practical) & 4,434 & 4,434 & 37.57 & 45.20 & 8 & 6 \\
\hline Physics & 4,394 & 4,430 & 48.28 & 48.33 & 0 & 0 \\
\hline
\end{tabular}

Source: ECZ 2014 Examination report.

Table 1 generally suggest that candidates had poor responses in most of the topics. The mean scores for paper 2 and paper 3 for both years are very low.

Table 2: 2017 SC Summary of Performance in Physics (5054) by Paper.

\begin{tabular}{|l|l|l|l|l|l|l|}
\hline \multirow{2}{*}{ Physics (5054) } & \multicolumn{3}{l|}{ Candidature } & \multicolumn{2}{l|}{ Mean Score (\%) } & \multicolumn{2}{l|}{ Zero (\%) } \\
\cline { 2 - 8 } & 2016 & 2017 & 2016 & 2017 & 2016 & 2017 \\
\hline Paper 1 (Theory) & 4,374 & 5,294 & 40.68 & 43.15 & 0 & 1 \\
\hline Paper 2 (Theory) & 4,377 & 5,309 & 34.43 & 43.34 & 20 & 22 \\
\hline Paper 3 (Practical) & 4,363 & 4,896 & 44.55 & 47.70 & 4 & 7 \\
\hline Physics & 4,354 & 5,317 & 38.59 & 44.34 & 0 & 0 \\
\hline
\end{tabular}

Source: ECZ 2017 Examination report.

Generally, majority of the candidates managed to respond to most of the questions but inadequacies were observed in certain topics such as electronics, thermal energy, electromagnetic induction, light and wave motion (Examination Council of Zambia, 2017 examination performance report, p 39). The inadequacies in the mentioned topics by the Chief Examiner report shows that learners had difficulties in understanding some scientific concepts and principles. Lack of understanding by the learners can also be as a result of poor lesson delivery by the teachers in these topics.

The teaching method was sought after looking at the challenges learners face to understand scientific concepts and principles, and challenges some teachers face to present material in a concrete way in physics from experience as a subject teacher. Therefore, it is important that edutainment be integrated in the teaching and learning process of thermal physics in order to capture the learner's attention and feelings. 


\subsection{Purpose of the Study}

This study was aimed at exploring the impact of edutainment on grade 11 learners' performance in thermal physics. It also attempted to identify the impact of edutainment on learners' perception in thermal physics. It further attempted to explore the difference in posttest mean scores between experimental group and control group and investigate the relationship between learner's achievement and perception.

\subsection{Research Objectives}

This study was guided by the following four research objectives;

1. To explore the impact of edutainment on grade 11 learners' performance on achievement test in thermal physics.

2. To establish the impact of edutainment on learners' perception in thermal physics.

3. To establish the difference in post-test mean scores between experimental group and control group.

4. To investigate if there is relationship between Learners achievement and perception.

\subsection{Research Questions}

This study was guided by the following four research questions;

1. What is the impact of edutainment on grade 11 learners' performance on achievement test in thermal physics?

2. What is the impact of edutainment on learners' perception in thermal physics?

3. What is the difference in post-test mean scores between experimental group and control group?

4. Is there relationship between Learners achievement and perception?

\subsection{Significance of the Study}

The findings of this research study will help learners to become creative thinkers and problem solvers. It will also help teachers to cultivate interests in the learners during the lesson thereby increasing learner's participation and improving their understanding in scientific concepts and principles. The findings could also influence teachers to impact positive perception in the learner and help them change their negative perception towards challenging topics in physics hence improving the performance. Lastly, the findings could help physics teachers in secondary schools to make policies that will promote the use of edutainment in the teaching and learning process. This method may also help other science subjects.

\subsection{Theoretical Framework}

Edutainment methods promotes the teaching and learning in which content of education is merged with the activities of entertainment in order to increase learner's participation, motivation and emotion. This method normally involves the use of visual representation to attract the learner's attention and creating active learning environment in physics. According to Buckingham and Scanlon (2005), edutainment is "a combination that heavily depends on visual material, on narrative or educational computer games. Edutainment is a teaching and learning approach which can involve any of the following; play, poetry, computer simulation, academic films and music, multimedia, websites and computer software. Edutainment is a type of entertaining whose aim is to include entertainment variety in the teaching and learning process in order to make learning more enjoyable. The entertaining variety includes multimedia software, internet sites, music, films, video and computer games and TV programs in order to exhilarate in addition to educate (Colace et 
International Journal of Scientific and Research Publications, Volume 10, Issue 5, May 2020

ISSN 2250-3153

al.2006). The teaching and learning should be entertaining in order to capture the mind of the learner hence improving their understanding of scientific concepts. Edutainment approach helps learners to connect to the real life and this can enhance the quality of student learning, and understanding. Edutainment is to execute permanence of learning by attracting learners' attention and regenerating their feelings (Okan, 2003).

Edutainment employs teaching and learning methods that attract learners' attention in order to provide learners' individual development in learning environments (Fossard, 2008). Therefore, the purpose of the study is to explore how edutainment can be used to improve the learner's performance in thermal physics using approaches such as computer simulation and poetry.

\subsection{RESEARCH METHODOLOGY}

\subsection{Research Design}

This research study used the quasi-experimental design. In this research design, intact groups were used by the researcher. In quasiexperimental design, the researcher assigned intact classes to the experimental and control groups, administered a pre-test to both groups, conducted experimental treatment activities with the experimental group only, and then administered a post-test to assess the differences between the two groups (Creswell, 2008). The topic of thermal physics in the experimental group was taught using edutainment that is CSP and the control group was taught using CL.

One of the most commonly used quasi-experimental designs in educational research can be represented as:

$\begin{array}{cccc}\text { Experimental } & \mathrm{O}_{1} & \mathrm{X} & \mathrm{O}_{2} \\ & -------- \\ \text { Control } & \mathrm{O}_{3} & & \mathrm{O}_{4}\end{array}$

Where:

The dashed line separates the experimental and control groups which have not been equated by randomisation.

$\mathrm{O}_{1}$ and $\mathrm{O}_{3}$ represents observations that were made during the pre-test measures. Experimental and control groups were both first given the Thermal Physics Achievement Test (TPAT) as pre-test measures.

$\mathrm{X}$ represents the treatment employed in order to assess its impact on learners 'performance on achievement test on thermal physics. Experimental group was taught using edutainment that is CSP while control group was taught using Cooperative Learning (CL).

$\mathrm{O}_{2}$ and $\mathrm{O}_{4}$ represents observations that were made during the post-test measures. Both experimental and control groups were given TPAT as the post-test measure.

\subsection{Research Site and Setting}

This study was conducted from St. Margret's Girls' Secondary School in Chipangali District Eastern Province of Zambia. St. Margret's Girls Secondary School is located in Chief Chanje's Chiefdom about 42 kilometres away from Chipata city main post office. 


\subsection{Research Instruments}

\section{Achievement test}

Thermal physics achievement test was made by the researcher. The test items constructed were measuring both the knowledge and problem-solving skills. These test items were extracted from Examination Council of Zambia and Cambridge International Past Examination Papers. This instrument was administered as a pre-test and post-test. For both pre-test and post-test, 1 hour 30 minutes time was given to write the test. Pilot testing was done in order to fine tune and also to increase the validity and reliability of the data collecting research instrument. The achievement test had two sections; sections A and B. Section A had 10 multiple choice questions; each question item with four (4) possible answers to choose from and each correct answer was given one (1) mark. Section B had 30 marks with 5 structured question and each having sub-questions. The total marks for the two sections was 40 marks. The test items constructed were measuring both the knowledge and problem-solving skills.

\section{Questionnaire}

In this study, a questionnaire was used to collect information from learners in thermal physics. The type of questionnaire item which was employed was rating scale-Likert scale. The Likert scale composed of 23 closed statements gathering information on the impact of edutainment on learner's perception towards thermal physics. Each statement had five-point rating scale of strongly agree, agree, not sure, disagree, and strongly disagree.

\subsection{FINDINGS AND DISCUSSION}

The research findings are presented according to the research questions.

\subsection{Presentation of findings for research question 1}

What is the impact of edutainment on grade 11 learners' performance on achievement test in thermal physics?

In order to find out the performance of the learners in achievement test, a paired sample t-test was used to determine if there was change in performance between pre-test and post-test for control group and experimental group.

In order to compare the pre-test and post-test scores for Control group, a paired sample t-test was conducted. Table 3 shows the mean and Standard Deviation (SD) and table 4 shows paired sample t-test for control group.

Table 3: Pre-test and Post-test Mean Scores and SD for Control Group ( $n=44)$

\begin{tabular}{|ll|c|c|c|c|}
\hline & & Mean & $\mathrm{n}$ & Std. Deviation & Std. Error Mean \\
\hline \multirow{2}{*}{ Pair 1 } & Pre-test & 14.909 & 44 & 6.678 & 1.007 \\
& Post-test & 34.614 & 44 & 11.126 & 1.677 \\
\hline
\end{tabular}

The results in table 3 show the learners scores in pre-test (Mean=14.909 and $\mathrm{SD}=6.678)$ and learners scores in post-test (Mean= 34.614 and $\mathrm{SD}=11.126$ ). In addition, the standard error mean (which reflects the amount of accuracy in estimating the data value in the entire population by using data value of only a sample) for pre-test is 1.007 and for post-test is 1.677 . 
Table 4: Paired Sample T-test for Control Group $(n=44)$

\begin{tabular}{|c|c|c|c|c|c|c|c|c|}
\hline & Paired D & rences & & & & & & \\
\hline & & Std. & Std. Error & $\begin{array}{l}95 \% \mathrm{Cc} \\
\text { of the } \mathrm{D}\end{array}$ & $\begin{array}{l}\text { dence Interval } \\
\text { rence }\end{array}$ & & & \\
\hline & Mean & Deviation & Mean & Lower & Upper & $\mathrm{t}$ & df & Sig. (2-tailed) \\
\hline $\begin{array}{c}\text { Pair } 1 \\
\text { Pre-test-Post-test }\end{array}$ & -19.705 & 11.621 & 1.752 & -23.238 & -16.171 & -11.247 & 43 & .000 \\
\hline
\end{tabular}

The results in table 4 show difference in mean of -19.705, Standard Deviation (SD) of 11.621 and Standard Error Mean of 1.752 between pre-test and post-test scores for control group. The $t$-value of -11.247 and two tailed p-value of 0.000 i.e. $t(43)=-11.247$, $p=$ 0.000. At standard alpha level of $0.05,0.000$ is less than 0.05 which suggest that there is significance difference between pre-test scores and post-test scores in the control group.

In order to compare the pre-test and post-test scores for Experimental group, a paired sample t-test was conducted. Table 5 shows the mean and Standard Deviation (SD) and table 6 show paired sample t-test for experimental group

Table 5: Pre-test and Post-test Mean Scores and SD for Experimental Group (n=36)

\begin{tabular}{|cc|c|c|c|c|}
\hline & & & & & \\
& & Mean & $\mathrm{n}$ & Std. Deviation & Std. Error Mean \\
\hline \multirow{2}{*}{ Pair 1 } & Pre-test & 14.639 & 36 & 7.492 & 1.249 \\
& Post-test & 57.833 & 36 & 13.656 & 2.276 \\
\hline
\end{tabular}

The results in table 5 show the learners scores in pre-test (Mean=14.639 and $\mathrm{SD}=7.492)$ and learners scores in post-test (Mean= 57.833 and $\mathrm{SD}=13.656$ ). In addition, the standard error mean for pre-test is 1.249 and for post-test is 2.276 .

Table 6: Paired Sample T-test for Experimental Group $(n=36)$

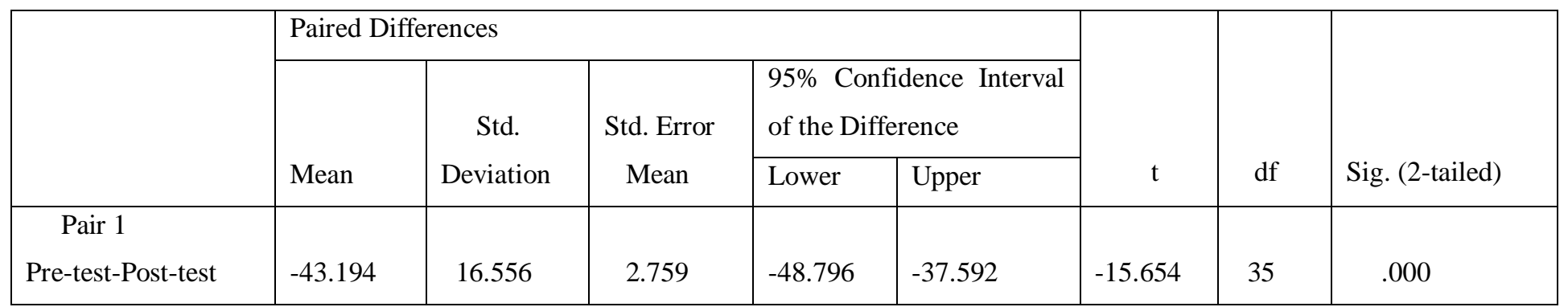

The results in table 6 show difference in mean of -43.194, Standard Deviation (SD) of 16.556 and Standard Error Mean of 2.759 between pre-test and post-test scores for experimental group. The t-value of -15.654 and two tailed p-value of 0.000 i.e. $t(35)=-$ 15.654, $\mathrm{p}=0.000$. At standard alpha level of $0.05,0.000$ is less than 0.05 which suggest that there is significance difference between 
pre-test scores and post-test scores in the experimental group. Therefore, we reject the null hypothesis which asserts that Edutainment approach has no impact on grade 11 learners' performance on achievement test in thermal physics.

The pre-test mean score for control group was 14.909 and for the experimental group was 14.639. The post-test results show a mean of 34.614 for control group and 57.833 for experimental group. This suggest that the use of Edutainment approach in teaching and learning of thermal physics improves learner performance in thermal physics in experimental group than those in control group where cooperative learning method was used. The results of this study are similar to those of Edsall \& Wentz, (2007) and Candida et.al, (2014). The results revealed that the mean scores for the learners in the experimental group were significantly greater than those in the control group meaning that CSP increases learners understanding of scientific abstract concepts and makes them to become creative thinkers.

Visual representations have been found to help students construct "mental models"

(Johnson-Laird, 1983) to explain scientific concepts and principles that are used to clarify natural phenomena (Gilbert, Boulter, \& Elmer, 2000; Gilbert \& Priest, 1997). Therefore, visual representation such as computer simulation lessons in thermal physics can help learners to construct mental models and to understand scientific concepts and principles easily hence enhancing their performance.

\subsection{Presentation of findings for research question 2}

\section{What is the impact of edutainment on learners' perception in thermal physics?}

The information on the impact of edutainment on learner's perception towards thermal physics was obtained from the questionnaire on perception. The mean scores for both the positive items and negative ones were calculated. The mean scores (x) ranged from $3<x$ $\leq 5$ for favorable feelings and $1 \leq \mathrm{x}<3$ for unfavorable feelings.

Table 7 shows a summary of the mean ratings for 36 learners for both positive and negative statements based on their responses.

Table 7: Mean Ratings for Both Positive and Negative Statements Based on Learners' Responses.

\begin{tabular}{|l|c|c|c|}
\hline \multicolumn{1}{|c|}{ Statement } & Mean & $\begin{array}{c}\text { Std. } \\
\text { Deviation }\end{array}$ & $\mathrm{n}$ \\
\hline Use of poetry makes me understand physics concepts better. & 3.50 & 1.342 & 36 \\
Use of computer simulation makes learning more active and enjoyable. & 4.47 & .971 & 36 \\
$\begin{array}{l}\text { Use of computer simulation and poetry motivate me to learn thermal physics. } \\
\text { I think that use of edutainment approaches makes learning more effective. }\end{array}$ & 4.08 & 1.079 & 36 \\
$\begin{array}{l}\text { I believe that use of computer simulation and poetry can improve my performance } \\
\text { in thermal physics. }\end{array}$ & 4.44 & .843 & 36 \\
$\begin{array}{l}\text { The use of computer simulation and poetry in learning thermal physics consumes } \\
\text { time. }\end{array}$ & 2.72 & 1.085 & 36 \\
$\begin{array}{l}\text { I can still learn better without the use of computer simulation and poetry in } \\
\text { thermal physics. }\end{array}$ & 2.83 & 1.464 & 36 \\
$\begin{array}{l}\text { Computer simulation and poetry are a valuable teaching tools for learning thermal } \\
\text { physics. }\end{array}$ & 3.86 & 1.150 & 36 \\
\hline
\end{tabular}

This publication is licensed under Creative Commons Attribution CC BY. http://dx.doi.org/10.29322/IJSRP.10.05.2020.p10142 
International Journal of Scientific and Research Publications, Volume 10, Issue 5, May 2020 ISSN 2250-3153

\begin{tabular}{|c|c|c|c|}
\hline $\begin{array}{l}\text { I can understand equally the same even without the use computer simulation and } \\
\text { poetry. }\end{array}$ & 2.86 & 1.199 & 36 \\
\hline Use of computer simulation and poetry can make me to be creative. & 3.19 & 1.238 & 36 \\
\hline $\begin{array}{l}\text { The use computer simulation helps to convey meaning that cannot possibly be put } \\
\text { across in words. }\end{array}$ & 4.56 & .735 & 36 \\
\hline Use of computer simulation and poetry help me understand quickly. & 4.03 & 1.028 & 36 \\
\hline $\begin{array}{l}\text { computer simulation and poetry help to convey scientific ideas more effectively } \\
\text { and memorably. }\end{array}$ & 3.86 & 1.397 & 36 \\
\hline Use of computer simulation and poetry help improve communication. & 4.50 & .811 & 36 \\
\hline $\begin{array}{l}\text { Use of computer simulation and poetry helps me transfer abstract concepts to other } \\
\text { contexts. }\end{array}$ & 4.53 & 1.000 & 36 \\
\hline Edutainment can reduce failure rate in thermal physics. & 4.39 & 1.022 & 36 \\
\hline Computer simulation and poetry increase educational effects. & 4.28 & .914 & 36 \\
\hline Computer simulation helps to show everything needed to be known appropriately. & 3.58 & 1.204 & 36 \\
\hline Use of edutainment allows self-evaluation. & 4.47 & .845 & 36 \\
\hline $\begin{array}{l}\text { Use of edutainment is worth and necessary for me to get high scores in thermal } \\
\text { physics. }\end{array}$ & 4.50 & .878 & 36 \\
\hline Edutainment makes learning a meaningful experience. & 4.14 & 1.125 & 36 \\
\hline Edutainment helps me interpret information easily. & 4.53 & .971 & 36 \\
\hline Use of computer simulation and poetry is sufficiently clear and precise. & 4.44 & .773 & 36 \\
\hline
\end{tabular}

Table 7 shows that the mean ratings for all the positive and negative statements. Where the mean is high, it shows that the use of CSP as edutainment methods changes the learner's perception towards thermal physics positively. They seem to agree to almost all the statements with mean greater than 3.0 that the use of edutainment can change learner's perception towards thermal physics. However, their response to the statements, 'use of CSP in teaching and learning thermal physics consumes time' and also 'I can still learn better without the use of CSP in thermal physics' was surprising. Most of the learners seemed to agree with the statements. This entails that although learners appreciate that using edutainment that is CSP would improve their performance in thermal physics, they are yet to see the value of edutainment and also on time consumption. They have also agreed to the statement that, "I can understand equally the same even without the use computer simulation and poetry."

Use of computer simulation entertains the learners during the lesson thereby motivating and making them to have a positive perception towards thermal physics. From the results, we can see that the mean ratings were high with almost all the statements having mean greater than 3.0. This showed that they agreed to most of the statements. Learners were hopeful that indeed the use of CSP not only makes learning more joyous but also enhances understanding of scientific concepts and principles that are abstract. Therefore, use of edutainment has a positive impact towards learners' perception towards thermal physics.

\subsection{Presentation of findings for research question 3}

What is the difference in post-test mean scores between experimental group and control group? 
Table 8 show the mean and Standard Deviation (SD) and table 9 show independent sample test for post-test results for 80 learners from experimental group and control Group.

Table 8: Post-test Mean Scores and SD between Experimental Group and Control Group.

\begin{tabular}{|l|l|l|l|l|l|}
\hline & Group Designs & $\mathrm{n}$ & & Std. Deviation & $\begin{array}{l}\text { Std. Error } \\
\text { Mean }\end{array}$ \\
\hline \multirow{3}{*}{ Post-test } & Control Group & 44 & 34.636 & 11.106 & 1.674 \\
& & & & & \\
& Experimental Group & 36 & 57.833 & 13.656 & 2.276 \\
\hline
\end{tabular}

The results in the table 8 show that the mean for participants in the control group is 34.64 and in the experimental group is 57.83 . In addition, the Standard Deviation (SD) the variation in the data (i.e. spread of scores) is a bit wider for Experimental group ( $\mathrm{SD}=$ 13.66) than the Control group ( $\mathrm{SD}=11.11)$.

In order to interpret the difference between the mean and whether they were statistically significant, an independent sample test was conducted as shown table 9 .

Table 9: Independent T-test with Equal Variance Assumed.

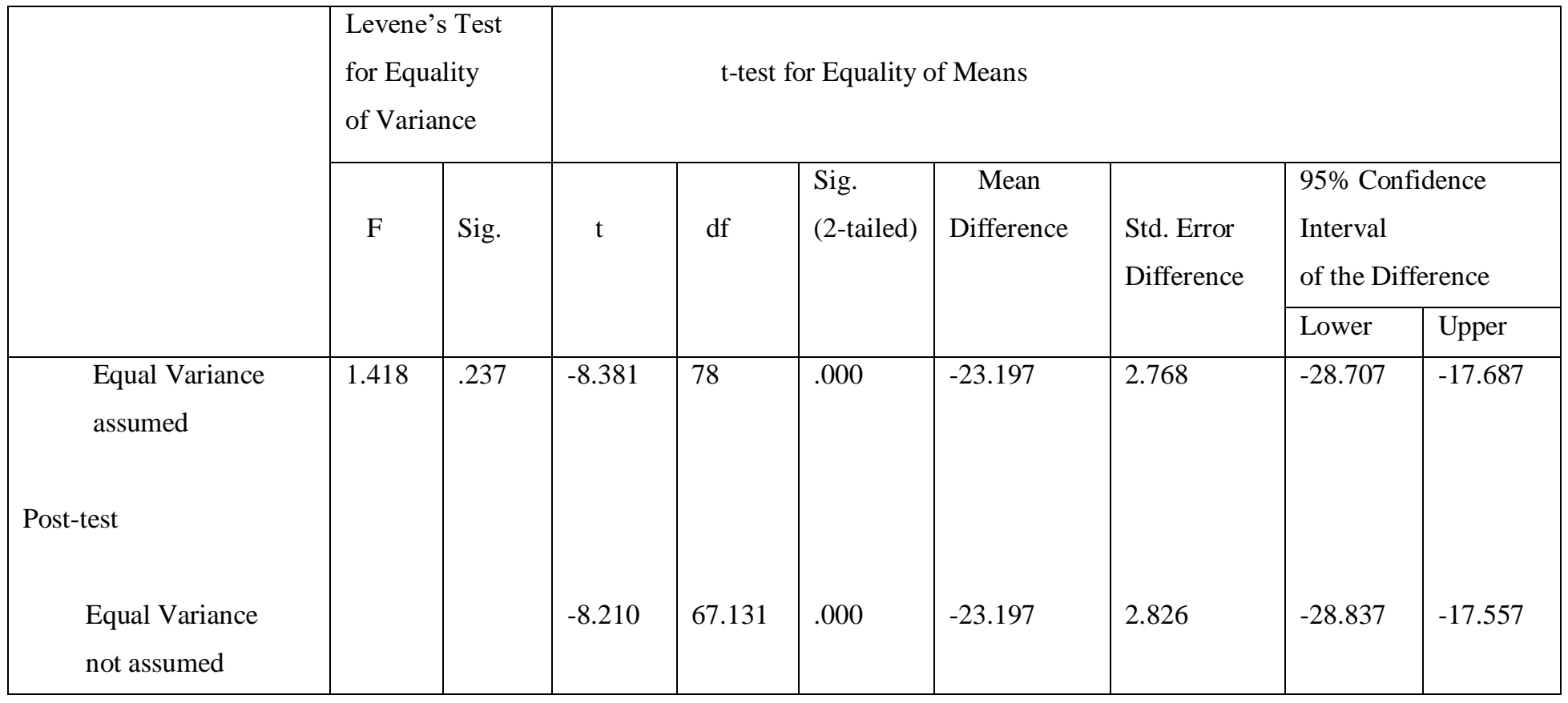

The results from the table show that the sig. (P-value) of Levene's test is 0.237 at 0.05 level of significance or alpha level. Since p> 0.05 , then the variances for the two groups are equal.

From the $\mathrm{t}$-test for Equality of Means, the t-test is significant as the $\mathrm{p}$-value is less than the $\alpha$-level (0.05) i.e. $\mathrm{t}(78)=-8.381, \mathrm{p}=0.000$. This means that there is statistically significant difference in achievements between the two groups in the post-test. This suggest that there is enough evidence that there is a difference in post-test mean scores between control group and experimental group. 


\subsection{Presentation of findings for research question 4}

Is there relationship between Learners achievement and perception?

A Pearson correlation analysis was conducted to examine whether there was a relationship between learners' achievement and perception.

Table 10: Correlation Matrix of Achievement and Perception $(n=80)$

\begin{tabular}{|lc|c|c|}
\hline & & $\begin{array}{l}\text { Learners' perception } \\
\text { in thermal physics }\end{array}$ & $\begin{array}{l}\text { Learners' } \\
\text { achievement in } \\
\text { thermal physics }\end{array}$ \\
\hline $\begin{array}{l}\text { Learners' perception } \\
\text { in thermal physics }\end{array}$ & Pearson Correlation & 1 & .174 \\
& Sig. (2 tailed) & & .311 \\
Learners' achievement & Pearson Correlation & 36 & 36 \\
in thermal physics & Sig. (2 tailed) & .174 & 1 \\
& $\mathrm{n}$ & .311 & 80 \\
\hline
\end{tabular}

The results show Pearson correlation coefficient $r=0.174, p=0.311$ in a two tailed test and at 0.05 level of significant. The correlation between learner's achievement and learner's perception towards thermal physics is positive. Since $\mathrm{P}>0.05$, the correlation between learner's achievement and their perception are not statistically significant. This implies that learner's performance on achievement test and their perception towards thermal physics after intervention has a weak positive correlation. This weak correlation could be as a result of using a relatively small sample size. This may limit the power of the statistics to reveal the relationship between learner's achievement and their perception. This may also explain why the p-value is greater than the alpha level.

\section{Conclusion}

This study investigated the impact of edutainment in improving learner's performance in thermal physics. The study revealed that the use of edutainment methods such as computer simulation and poetry in teaching and learning has positive impact on the learner's academic performance in thermal physics. The study also investigated that the use of edutainment helps learners to understand scientific concepts and principles easily and fosters the development of problem-solving skills. It was also discovered that edutainment made some learners who had difficulties before intervention to develop positive perception towards thermal physics. Lastly, the study revealed a positive correlation between learners' achievement and their perception.

\subsection{General Recommendations}

1. Physics teachers in their classes to include more real-life problems in order to attract learner's attention.

2. The Education system should introduce a policy that will sensitise the communities on the importance of science and technology in the country. Parents should also encourage or support their children to take up physics in order to become technicians, miners, engineers and teachers of physics.

3. Physics teachers to use visual representation for abstract concepts and principles as this will enhance learners understanding.

4. The school managers and other stakeholders should provide facilities such as internet which are important for computer simulation.

5. A similar research study can be undertaken in other abstract topics in physics to see whether similar results can be obtained as this will strengthen the findings of this research study. 
6. A research study can be undertaken in other science subjects to investigate the impact of edutainment using CSP.

7. Other research methods of edutainment rather than CSP be carried out in the same topic or other physics topics.

8. This research study used a small sample size from one school, the researcher recommends that wider area and more schools be involved in order to strengthen the findings of this study.

\section{References}

[1] Argan, M. \& Sever, N. S. (2010). Constructs and Relationships of Edutainment Applications in Marketing Classes: How Edutainment Can be Utilized to Act as a Magnet for Choosing a Course? Contemporary Educational Technology, pp. 118-133.

[2] Candida, S., Jose, P., \& Armando, A. (2014). Contribution of a computer simulation to students learning of the physics concepts of weight and mass. Elsevier Ltd. Science journal

[3] Cohen, L., \& Manion, L. (1995). Research methods in Education. London: Routledge.

[4] Cohen, L., \& Manion, L. (1994). Research methods in Education (4th Ed.). London: Routledge.

[5] Colace, F., De Santo, M. \&Pietrosanto, A. (2006). Work in Progress: Bayesian Networks for Edutainment, 36th ASEE/IEEE Frontiers in Education Conference, DOI: 10.1109/FIE.2006.322573.

[6] Creswell, J.W. (2003). Research design: Qualitative, Quantitative, and Mixed methods approaches (2nd ed.). thousand Oaks, CA: Sage.

[7] Creswell, John W, (2008).4th ed, Educational research: planning, conducting, and evaluating quantitative and qualitative research. University of Nebraska Lincoln.

[8] Cronbach, L.J., Shavelson, R.J. (2004). My Current Thoughts on Coefficient Alpha and Successor Procedures Educational and Psychological Measurement, 64 (3), 391-418.

[9] Douglas, B. (1969) Language, the Learner and the School. Harmondsworth: Penguin. Eastwell, P. (2002).

Poetry: Adding passion to the science curriculum. Science Education Review, 1, 2.

[10] Examination Council of Zambia, 2014 MGE, Lusaka

[11] Examination Council of Zambia, 2017 MGE, Lusaka

[12] Florence, D., \&Terry, G. (1984) Reading for Learning in the Sciences. Edinburgh: Oliver and Boyd.

[13] Fossard, E.D. (2008). Using Edu-Tainment for Distance Education in Community Work, Sage Publications, 2008, pp. 19.

[14] Frazier, W., \& Murray, K. (2009). Science poetry in two voices: Poetry and the nature of science. School Science Review, 8(2), 58-78.

[15] Gilbert, J., \& Priest, M. (1997). Models and discourse: A primary school science class visit to a museum. Science Education, 81(6), 749-762.

[16] Hadzigeorgiou, Y. (2016). Imaginative science education. Cham: Switzerland: Springer International.

[17] Herrick, R., \& Cording, R. (2013). Using a poetry reading on hemoglobin to enhance subject matter. Journal of Chemical Education, 90, 215-218.

[18] Jegede, P. O., Odusola, O. D, Ilori, M. O. (2007). Relationships between ICT competence and attitude among Nigerian tertiary institution Lecturers. Educational Research and Review, 2(7), 172-175.

[19] Jerry, W \& Jonathan, O. (2001) Language and Literacy in Science Education

[20] Kerlinger, F. N. (1979). Behavioral research: A conceptual approach. New York: Holt, Rinehart, \& Winston.

This publication is licensed under Creative Commons Attribution CC BY. 
International Journal of Scientific and Research Publications, Volume 10, Issue 5, May 2020

[21] Kombo, D.K., \&Tromp, D.L. (2006). Proposal and Thesis writing. Makuyu: Don Bosco printing press.

[22] LaBonty, J., \& Danielson, K.E. (2005). Writing poems to gain deeper meaning in science. Middle School Journal, 36(5), 30-36.

[23] Lemmer, E. (2000). Contemporary Education; global Issues and Trends. Sandton: Heinemann Higher and further Education (Pvt) Ltd.

[24] Lesley, B. (1985) Teaching Language and Study Skills in Secondary Science. London: Heinemann.

[25] Mugenda, O. M., \& Mugenda, A. G. (1999). Research methods: Quantitative and Qualitative Approaches. Acts Press, Nairobi.

[26] Nalan, A. (2015). Theoretical view to the approach of edutainment. Elsevier Ltd. Turkey.

[27] Okan, Z. (2003). Edutainment: Is Learning at Risk? British Journal of Educational Technology, pp. 255264.

[28] Orodho, J. (2003). Essentials of Educational and social science research methods. Masola Publishers. Nairobi.

[29] Sieber, J. E. (1998). Planning ethically responsible research. In L. Bickman \& D. J. Rog (Eds.), Handbook of applied social research methods (pp. 127-156) Thousand Oaks, CA: Sage.

[30] Watts, M. (2001). Science and poetry: passion v. prescription in school science? International Journal of Science Education, 23, 197-208. 